\title{
THE PRACTICAL IMPORTANCE OF AN IDENTIFICATION OF GARDEN PEA VARIETIES IN THE SEEDLING STAGE
}

\author{
J. M. ANDEWEG and A. VAN KOOTEN \\ Institute of Horticultural Plant Breeding, Wageningen
}

Received 19 Aug. 1957

\section{INTRODUCTION}

A quick identification of garden pea varieties may be very useful as far as it permits an effective check on the identity and purity of seeds grown for commercial purposes. It would be very attractive if, with the help of seed and young plant characters, the observations could be made in winter, between the last harvest and the next sowing.

Seed characters are helpful but of limited use for the identification of a variety. VAN DER VAART (4) described the identification of pea varieties in the seedling stage. He found that when the leaf in the third node is developed, the shape of the first two leaves (scales) of young seedlings is very characteristic. In this way VAN DER VAART, could distinguish fourteen agricultural pea varieties. Using VAN DER VAART's method G. P. Morris (2) distinguished 40 pea varieties, including some garden peas, while PETERS (3) distinguished 20 varieties, mainly horticultural peas.

At the Institute of Horticultural Plant Breeding, Wageningen, the present writers have tried to find out if the characters of the first two leaves could be used for the identification of all the garden pea varieties in their collection (about 500 varieties) and for an effective check of the purity of commercial varieties.

\section{MATERIAL AND METHODS}

During the winter months December and January young pea seedlings were grown in air-conditioned glasshouses at the Institute (1). All varieties were grown at a constant temperature of $20^{\circ} \mathrm{C}$, while some were also grown at a constant temperature of $26^{\circ} \mathrm{C}$ and $17^{\circ} \mathrm{C}$.

Seeds were sown in trays, filled with a mixture consisting of equal parts of sandy soil and peat, covered with a layer of coarse sand about $5 \mathrm{~cm}$ thick. Before sowing, the soil was watered thoroughly, to avoid watering and subsequent damping off during the growing period. Seeds were disinfected with T.M.T.D. and sown in the layer of sand. Additional light from 450 W Philips' H.O 2000 lamps was given from 8 a.m. 4 p.m.; one lamp per square meter, hanging $085 \mathrm{~m}$ above the soil surface. Thirty seeds of each variety were sown.

About twenty seedlings were used for preparing shadowgraphs of the leaf-scales. The plants used for the shadowgraphs were chosen at random; very weak plants were not used. At $20^{\circ} \mathrm{C}$ the shadowgraphs could be prepared 14 days after sowing, when the fourth leaf of the plants was about to unfold. The young plants were lifted and, if necessary, stored in polythene bags to avoid wilting. The scales were torn from the plants by bending them over the edge of a sharp knife (Fig. 1) and then put on the glass of a $13 \times 18 \mathrm{~cm}$ photographic printing frame. The glass had previously been 


\section{J. M. ANDEWEG AND A. VAN KOOTEN}

moistened with water to avoid curling of the very small scales. The scales on the glass were covered first with a thin sheet of transparent polythene, then with a sheet of phototypic paper (ozalid black K) after which the printing frame was closed (Fig. 2).

If it is necessary to multiply the prints transparent ozalid Radex paper can be used successfully. After illumination the print was developed in ammonia. In this way shadowgraphs were made of a collection of about 500 garden pea varieties.

\section{INFLUENCE OF DIFFERENT GROWING TEMPERATURES}

Space sufficient to grow several hundreds of varieties was only available in an air-conditioned glasshouse with a constant temperature of $20^{\circ} \mathrm{C}$. To determine the influence of the growing temperature on the shape and size of the scales some varieties were also grown at a constant temperature of $26^{\circ}$ and $17^{\circ} \mathrm{C}$. Fig. 3 shows some typical

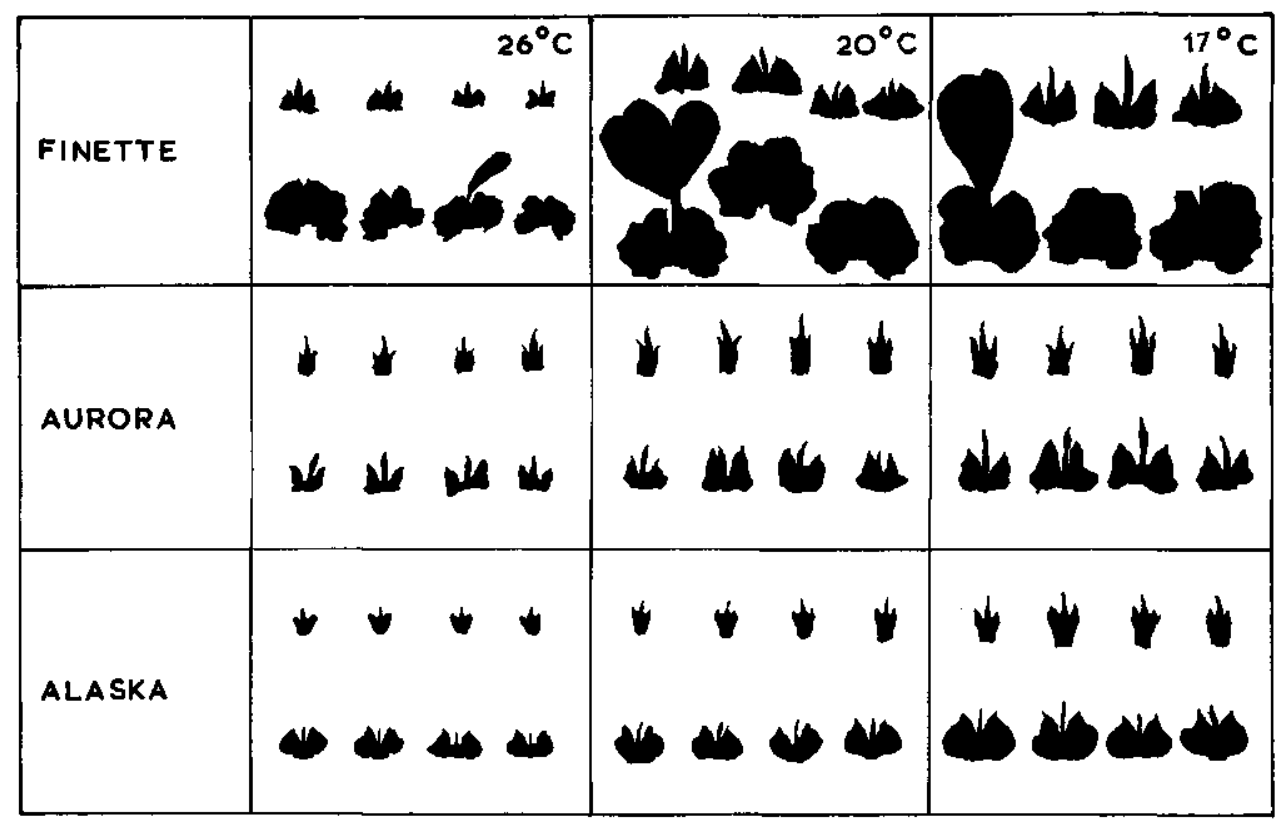

Fig. 3. Size AND SHAPE OF SCALES AT DIFFERENT TEMPERATURES. UPPER ROW OF EACH VARIETY FIRST SCALE, LOWER ROW SECOND SCALE

scales of the varieties Finette, Aurora and Alaska, grown at $26^{\circ}, 20^{\circ}$ and $17^{\circ} \mathrm{C}$ respectively. The shadowgraphs were made at the time at which the fourth leaf was about to develop. Apparently the shape of the scales changes only slightly with the different temperatures, but the size is strongly influenced. The scales are small at $26^{\circ}$, markedly larger at $20^{\circ} \mathrm{C}$ and larger still at $17^{\circ} \mathrm{C}$.

These differences in size occurred both in winter-grown plants that received additional light and in spring-grown plants without additional light. From this it follows that a reliable comparison of the scale shadowgraphs of a certain variety with 
IDENTIFICATION OF GARDEN PEA VARIETIES

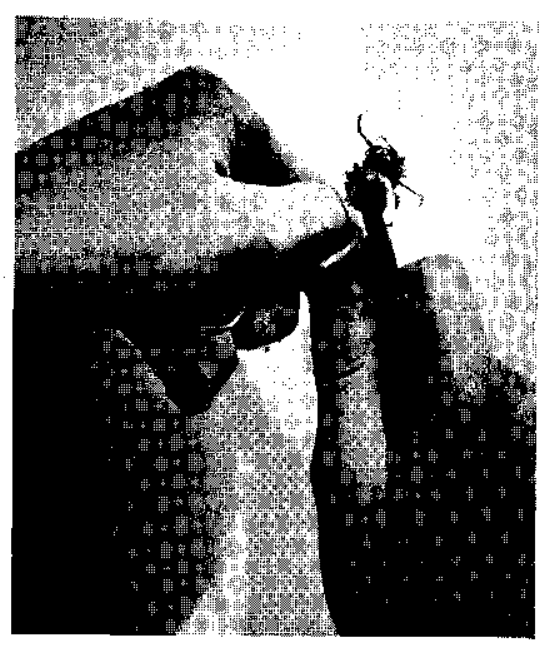

Fig. 1. Removal of SCale-leaves

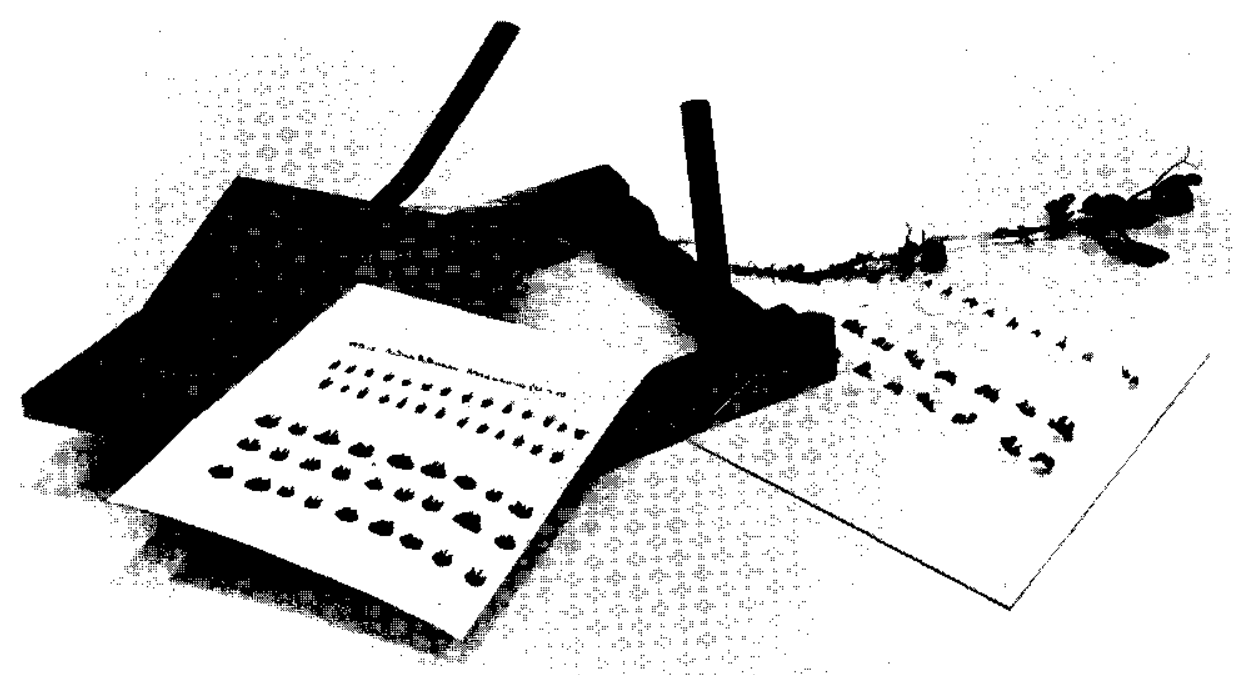

Fig. 2. Printing frame 


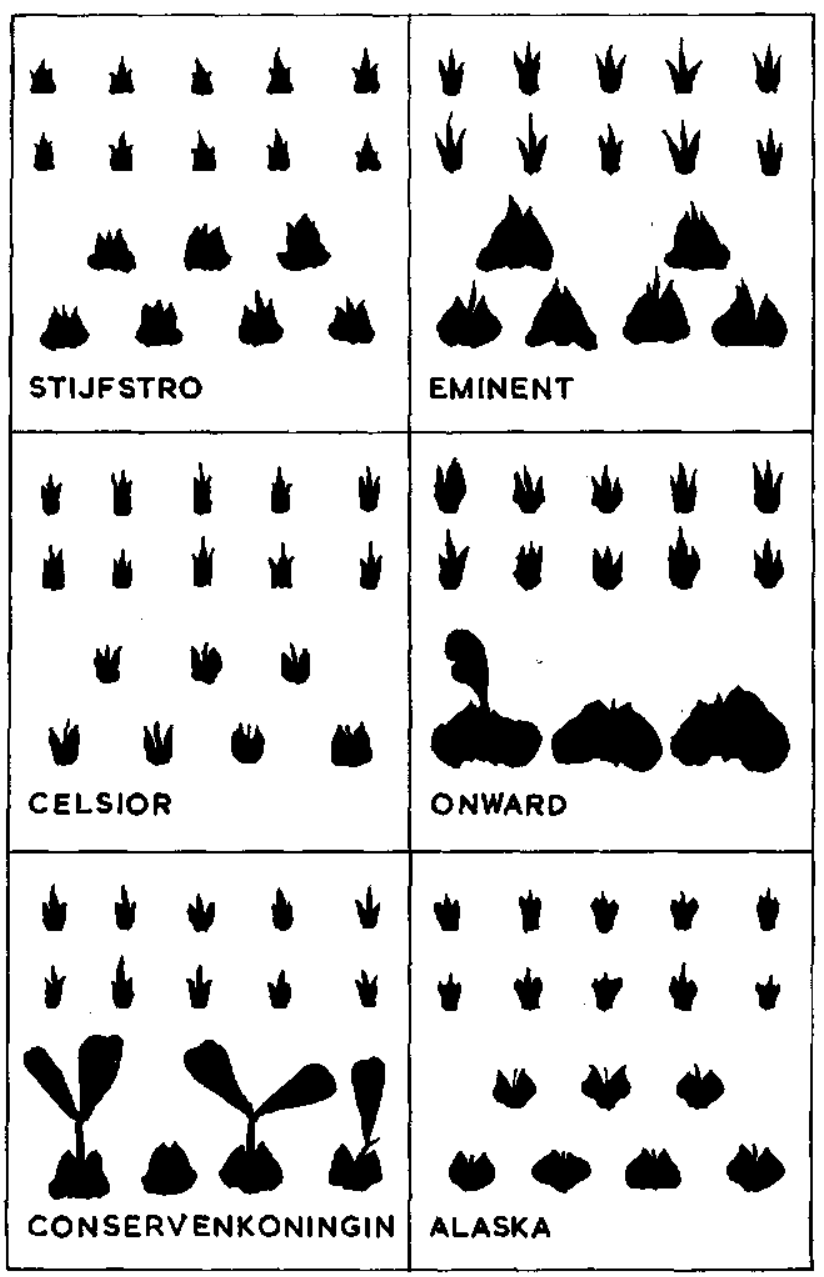

Fig. 6. SOME TYPICAL FIRST AND SECOND SCALES OF SIX PEA VARIETIES. UPPER TWO ROWS OF EACH VARIETY FIRST SCALE; LOWER ROW(S) SECOND SCALE

varieties, 13 mixtures were made at the institute by a co-worker, who in other respects was not concerned with these experiments. These mixtures contained three varieties at the most, the seed colour and scales of which were very much alike.

It was possible to detect that there was more than one variety in all the seed samples. Here differences in growth habit etc. of the young plants proved to be very useful for the detection. In most cases the names of the mixed varieties were determined. In a few cases it was impossible to determine all the varieties of the mixture correctly; if a third variety was present in the mixture it was not always discovered, due to the fact that it was not sufficiently distinct from the other varieties. The number of commercial varieties in current use in a certain country is much smaller than the large number of varieties used in the present experiments. Consequently the differences 
between the varieties when mixed will be greater than in our experiments, in which moreover mixtures were chosen of varieties that were very similar to each other.

So we may conclude that mixtures in commercial seed can nearly always be readily detected in the seedling stage of the plants. In most cases it is also possible to identify the mixed varieties.

\section{SUMMARY}

1. With the aid of the first and second scale, in combination with seed and other characteristics of the young plants, it is possible to identify the numerous commercial garden pea varieties.

A reliable comparison of scale shadowgraphs is only possible if the temperature conditions under which the young seedlings have grown have been as nearly identical as possible.

2. Mixtures in commercial seed can nearly always be readily detected in the seedling stage of the plants. In most cases it is also possible to identify the mixed varieties.

\section{SAMENVATTING}

De praktische betekenis van een identificatie van doperwtenrassen in het zaailingstadium

1. Het is mogelijk om met behulp van de eerste en de tweede knopschub, in combinatie met zaad- en andere eigenschappen van de jonge planten, het zeer grote aantal in de handel voorkomende doperwtenrassen te identificeren. Een betrouwbare vergelijking van lichtdrukken van de knopschubben is alleen mogelijk als de temperatuursomstandigheden, waaronder de zaailingen werden geteeld, zo goed mogelijk aan elkaar gelijk zijn.

2. Vermengingen in handelszaad kunnen meestal reeds in het zaailingstadium van de planten ontdekt worden. In de meeste gevallen is het ook mogelijk om de rassen in het mengsel te identificeren.

\section{LITERATURE}

1. BraAk, J. P. and SMeETs, L., The phytotron of the Institute of Horticultural Plant Breeding at Wageningen, Netherlands. Euphytica 5 (1956): 205-217.

2. MoRris, G. P., Investigations into the use of the first two leaves of pea seedlings in varietal identification. Journal of the National Institute of Agr. Bot. 6 (1953) : 489-493.

3. Peters, Nelson Spanier, Contribuição á identificação de variedades de ervilha (Pisum sativum L.) pela morfologia dos catafilos. Jornada de Agronomia do Rio Grande Do Sul. Dec. 1954.

4. VAART, F. M. VAN DER, The identification of pea varieties in the seedling stage. Euphytica 1 (1952): 29-33. 


\section{MEDEDELINGEN ${ }^{1}$ )}

\section{VAN HET INSTITUUT VOOR DE VEREDELING VAN TUINBOUWGEWASSEN}

50. Algemene Veredelingsdagen 1952. Verslag van voordracheen en discussies. Juni 1953 ....... f 1,50

51. Sneep, 1. Practijkproeven met Spitskool 1949-1950 en

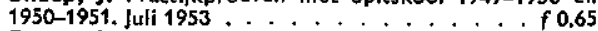

52. Boom, B. K. Internationaal reglement voor de naamgeving van gekweekte planten

53. Kronenberg, H. G. en F. Garretsen. Opbrengstproeven met aardbeiklonen. November 1953

54. Veredelingsdag Groentegewassen 1953. Verslag van voordrachten en discussies. December 1953 . . . . f 1.

55. Floor, J. Planten in plastic. Januari 1954 . Vitverkoche

56. Banga, $O$. Taproot-problems in the breeding of root vegetables

57. Jensma, J. R. en A. Kraai. Practijkproeven met Rode Kool 1950-1951. Juni 1954 .......... f 1.10

58. Jensma, 1. R. en A. Kraai. Practijkproeven met Spruitkool 1950-1951. Juli 1954.

59. Veredelingsdag Fruitgewassen $1954^{\circ}$. Verslag van voordrachten en discussies. Augustus 1954 . . . . f 0,95

60. Kraai, A. The use of Honey-bees and Bumble-bees in breeding work. September $1954 \ldots . . .$. . . 0,45

61. Jensma R. en A. Kraai. Practijkproeven met Witte Kool 1952-1953. Februari 1955 ... . . . f 1,35

62. Banga, $O$. en J. W. de Bruyn. Selection of Carrots for Carotene Content. Februari 1955 ...... . f 0,25

63. Kronenberg, H. G. en L. M. Wassenaar. Practijkproeven met aardbeirassen 1952-1954. April 1955 f 0,90

64. Keuls, M. and J. W. Sieben. Two statistical problems in plant selection. April 1955

f 0,35 65. Banga, 0 . The Institute of Horticultural Plant Breeding.

f 0,25

6. Banga, 0 . Uienveredeling met gebruikmaking van inteelt en herstel door heterosis. Juni 1955 . . . . . f 0,30

67. Banga, O. Carrot yield analysis. September 1955 . f 0,30

68. Banga, O., J. W. de Bruyn and L. Smeets. Selection of carrots for carotene content. II Sub-normal content at low temperature. September 1955

0.25

69. Braak, J. P. Effect of temperature and light on June Yellows in strawberries. September 1955 . . . . . f 0,25

70. Banga, $O$. De ontwikkeling van de rassensituatie bij groentegewassen. Oktober 1955 ....... f 0,25

71. Bruyne, A.S. de. Tendenzen in de ontwikkeling van het Nederlandse fruitsortiment. Oktober 1955 . . . . f 0,40

72. Banga, O. Praktijkproeven met Knolselderij 1953-1954. November 1955 . . . . . . . . . . . f 0,30

73. Floor, J., Proeven met stekken onder waterverneveling. April 1956

74. Andeweg, j. M. en J. H. Ruyten. Praktijkproeven met Tomaten 1954-1955. April 1956.

0.40

75. Andeweg, J. M. en A. van Steenbergen. Praktijkproeven met Stoksnijbonen 1953-1954. Mei 1956 . . . f 0,35

76. Banga, O. en J. L. van Bennekom. Praktjjkproeven met Ronde Witpunt Radijs 1953-1954. Mei 1956 . . f 0,55

77. Smeets, L. and Hester G. Kronenberg. Runner formation on strawberry plants in autumn and winter. . f Smeets, L. Runner formation on strawberry plants in autumn and winter. II. Influence of the light intensity on the photoperiodical behaviour. Juni 1956.... f 0,30

78. Smeets, $L$. Influence of the temperature on runner production in five strawberry varieties. Juni 1956 ? 0,25

79. 5 meets, L. and L. M. Wassenaar. Problems of heat spot in Fragaria vesca $L$. when indexing strawberry selections for viruses. Juni 1956

f 0,50

80. Banga, 0 . and $J$. W. de Bruyn. Selection of carrots for carotene content. III Planting distances and ripening equilibrium of the roots. Juni 1956

81. Banga, $O$. International conference on the improvement and on the standardization of vegetable varieties at Wageningen, Netherlands, on August 26 and 27, 1955. August 1956

82. Floor, J. Proeven met vermeerdering van houtige gewassen. September 1956

f 0.80

83. Gerritsen, C.J. Improvement of the cherry varieties used in the Netherlands. Oktober 1956. . . . . . f 0,35

84. Gerritsen, C.J. Research offered new possibilities for nut growing in the Netherlands. Oktober 1956... . f 0,25

85. Andewer, J. M. The breeding of scab-resistant frame cucumbers in the Netherlands. Oktober 1956 . . . , f 0,30

86. Zeilinga, A. E. An improved acetic orcein squash method for serial eytological preparations. Oktober 1956 f 0,20
87. Braak, J. P. and L. Smeets. The Phytotron of the institute of Horticultural Plant Breeding at Wageningen, the Netherlands. Oktober $1956 \ldots \ldots$........ f 0,30

88. Banga, 0 . and L. Smeets. Some effects of the photoperiod on growth and pithiness of radish. Oktober 1956

9. Kho, $Y$ ond $\mathbf{P}$ Braak Reduction in 0,3 viability of carrot seed in relation to the occurrence of the plant bug Lygus campestris L. Oktober 1956 . . . f 0,35

90. Terpstra, $W$. Some factors influencing the abscission of debladed leaf petioles. Oktober 1956 . . . . . f 0,35

91. Keuls, M. en J. J. Post. Invloed van de temperatuur op de groei yan asperges. Januari 1957 . . . . 0,70

92. Smeets, L. Some effects of the photoperiod on the shoot growth of cherry seedlings. Febr. 1957 . . f $\mathbf{0 , 3 0}$

93. Elzenga, G. and J. W. de Bruyn. Interrelation of alkaloid content and stage of development of 1- and 2-year -old-Atropa belladonna L. Febr, 1957 . . . . . . f 0,30

94. Elzenga, G., L. Smeets and J. W. de Bruyn. Influence of the temperature on growth and alkaloid content of first-year Atropa belladonna $L$. Februari 1957 . f 0,25

95. Ferguson, J. H. A. Some applications of binomial pro. bability paper in genetic analyses. Februari 1957 . f 0,35

96. Jensma, I. R. Teelt en veredeling van bloemkool. Maart 1957

97. Boom, B. 'K. Benaming, geschiedenis en kenmerken van een aantal houtachtige planten. Nomenclature. history and characteristics of some woody plants. Maart 1957

98. Gerritsen, c. J. De Feyoa, een nieuw cultuurgewas? Maart 1957 . . . . . . o, 0,40

99. Braak, J. P. Effects of some internal and external factors on the embryo and seedling development of the cherry.

100. Floor, J. Moisture as a factor in the rooting of cuttings. April 1957 ............... . f 0,65

101. Floor, J. Verslag van onderstammen-onderzoek. Mei 1957

f 2,10

102. Boom, B. K. Populus canadensis Moench versus Populus euramericana Guinier. April 1957 ...... f 0.40

103. Huysices, J. A. Moet Nederland groene en/of vezelvrije asperges gaan telen? Mei 1957 . . . . . . . . f 0,40

104. Andeweg, J. M. en A. van Sténbergen. Praktijkproeven met tuinbonen 1955-1956 . . . . . . f 0,40

105. Banga, O. Origin of the European cultivated carrot, and Banga, $\mathbf{O}$. The development of the original Eurcpean carrot material. Juni 1957 ........ . . $f 1,-$

106. Andeweg, J. M. and J. H. Ruyten, Seven years experience with hybrid tomatoes. Juni 1957 . . . . f 0,50

107. FJoor, J. Report on the selection of a dwarfing rootstock for cherries. Juni 1957. . . . . . . . . f 0.40

108. Banga, $O$. Horticultural plant breeding in the Netherlands. Juni 1957. . . . . . . . f 0,30

109. Giessen, A.C.van der and A. van Steenbergen. A new method of testing beans for Anthracnose. Juni 1957 f 0,30

110. Huysices, J. A. Praktijkproeven met witlof. Juli 1957

111. Ferguson, j, H, A. Photothermographs a cool for climate studies in relation to the ecology of vegetable varieties Oktober 1957

$f 0,55$

112. Sneep, l. Geschiedenis van de spinazie en het ontstaan van de rassen. Oktober 1957 . 2,10

113. Sneep, J. De stand van de veredeling bij spinazie. Dissertatie. Wageningen, november 1957 . . . . . . f 10,-

114. Smeets, L. Some effects of temperature in the shoot growth of cherry seedlings. Oktober 1957 . . . . f 0,50

115. Andeweg, J. M. en A. van Steenbergen. Praktijkproeven met pronkbonen 1955-1956. Oktober 1957

0,40

116. Garretsen, F. en H. G. Kronenberg. Opbrengstproeven met zwarte bessen. Oktober 1957 . . . f 0,55

117. Bruyn, 1. W. de. Het gehalte an mydriatische alkaloiden van Scopolia lurida. Oktober 1957 ... f 0,55

118. Floor, J. Verslag van proeven met stekken onder waterverneveling. Oktober 1957 . . . . . . f f 1,75

119. Braak, J. P. and A. E. Zeilinga. Production of a colchicine-induced tetraploid asparagus. December 1957

120. Andeweg, J.M. and A. van Kooten. The practical importance of an identification of garden pea varieties in the seedling stage. December $1957 . \ldots$.... f 0,45 


\section{RASSENLIJSTEN') \\ UITGEGEVEN DOOR HET INSTITUUT VOOR DE VEREDELING VAN TUINBOUWGEWASSEN}

Negende Beschrijvende Rassenlijst voor Fruit. 1958 in voor- Tiende Beschrijyende Rassenlijst voor Groentegewassen. bereiding 1958. Redacteur Dr. O. Banga ....... f

\section{PUBLIKATIES VAN HET INSTITUUT VOOR DE VEREDELING VAN TUINBOUWGEWASSEN IN ANDERE ORGANEN OF IN BOEKYORM EVENTUEEL IN SAMENWERKING MET ANDERE INSTELLINGEN²)}

De publikaties, waarvan prijs èn uitgever worden vermeld zijn verkrijgbaar in de boekhandel. Overigens wende men zich tor de opgegeven bronnen of tot de bibliotheek van het I.V.T.

Boom, B. K. Over een verzameling prijscouranten. De Boomkwekerij 11, 1956: 128-129.

Boom, B. K. Een Amerikaan over Boskoop. De Boomkwekerij 11, 1956: 130 .

Huyskes, J. A. Klauwenselectie bij asperges geeft goede resultacen. Boer en Tuinder (Land en Vee) 10, 1956; no. 482: 17

Koot, Y. v. en J. M. Andeweg. De groenteteelt in Amerika. 's-Gravenhage, C.O.P., $1956.149 \mathrm{blz}$. f 7,00.

Banga, 0 . Kweker en overheid in de sector groentezaden. Zaadbelangen 10, 1956: 189-190.

Kho, Y. O. Opbrengstvermindering en kiemkrachtverlaging van wortelzaad als gevolg van aantasting door wantsen. Zaadbelangen 10, 1956: 193-194.

Elzenga, G. Digitalis lanata Ehr. V.N.K.-Nieuws 1956: 167-170, 193-199.

Andeweg, J. M. Rationalisatie en rassenkeuze. Groenten en Fruit 12, 1956: 111.

Kho, Y. O. en J. P. Braak. Opbrengstvermindering en kiemkrachtverlaging van wortelzaad als gevolg van aantasting door wantsen. Meded. Dir. Tuinb. 19, 1956: 440-445.

Kronenberg, H. G. Praktijkproeven met aardbeien in 1956. De Tuinderij 36, 1956, no. 33: 1-3. Groenten en Fruit 12, 1956: 177.

Floor, J. en P. A. Wezelenburg. Stekken onder plastic. De Boomkwekerij 11, 1956: 174-175.

Terpstra, W. Some factors influencing the abscission of debladed leaf petioles. Acta Botanica Neerlandica 5, 1956 157-170.

Bruyne, A. S. de. Trends and developments in Dutch varieties. The Commercial Grower 1956, no. 3165: 419-422.

Smeets, L. A note on the shortening of the juvenile phase in cherry seedlings. Euphytica S, 1956:117-118.

Broertjes, C. Vorstsehade aan Rhododendronvariëteiten in 1956. De Boomkwekerij 11, 1956: 187-189.

Radenburg, C. M. Hec kweken van wolfresistente spinazierassen. Zaadbelangen 10, 1956: 325-326.

Andeweg, J. M. Een waardevolle vroege kruisingsouder. Zaadbelangen 10, 1956: 344

Huyskes, J. A. en C. M. Rodenburg. Internationale samenwerking bij het onderzoek van slarassen. Meded. Dir Tuinb. 19, 1956: 823-826.

Gerritsen, C. J. De teelt van buitenperziken I, II, III, IV. Groenten en Fruit 12, 1956: 537-538; 569-570; 603; 628-629.

Gerritsen, C. J. De Feyoa, een nieuw cultuurgewas? Meded. Dir. Tuinb. 19, 1956: 889-894.

Jensma, J. R. Sluitkoolrassen. Wageningen, I,Y.T. 1956: 150 blz. 113.50 .

Floor, J. Planten in plastic. Wageningen, I.V.T., 1956. f 0.35.

Elzenga, G. De reelt van Valeriaan, V.N.K.-Nieuws 4 1956: 234-236.
Elzenga, G. Het mechanisch rooien van Valeriaan. V.N.K.Nieuws 4, 1956: 246.

Elzenga, G. Het opkweken van plantmateriaal van Levisticum en Rheum. V.N.K.-Nieuws 4, 1956: 246-247.

Elzenga, G. Roest in munt. Zou gier helpen? V.N.K.-Nieuws 4, 1956:247.

Elzenga, $\mathbf{G}$. Mechanisch planten van Valeriaan blijkt zee goed mogelijk. V.N.K.-Nieuws 4, 1956: 248-249.

Elzenga, G. De oogstdatum van Digitalis lanata. V.N.K.Nieuws 4, 1956: 249-250.

Giessen, A. C. v. d. en A. v. Steenbergen. Een nieuwe methode voor de toetsing van bonen op resistentie tegen vlekziekte. Zaadbelangen 11, 1957: 26-27.

Nieuwhof, $M$. Vegetatieve instandhouding en vermeerdering bij koolgewassen. Zaadbelangen 11, 1957: 93-96, 110-112.

Kho, Y. O. Nogmaals wantsen en zaadteelt bij wortelen. Zaadbelangen 11, 1957: $78-79$

Wassenaar, L. M. Is het mogelijk het aardbeiras Climax door selectie toch vrij te houden van voorjaarsbont? Groenten en Fruit 12, 1957: 1064

Andeweg, J. $M$. Kamkommerhybriden. Zaadbelangen 11 1957: 127.

Rodenburg, C. M. Het herkennen van slarassen aan de jonge plant. Groenten en Fruit 12, 1957: 1130-1131.

Komen, G. Belangrijke rassen yoor particuliere detaillisten. Zaadbelangen 11, 1957: 165-167.

Huyskes, J. A. en C. M. Rodenburg. International collaboration in the study of varieties of lettuce. Euphytica 6 . 1957: 94-95.

Rodenburg, C. M. Zaadteelt van slakroppen in de volle grond geselecteerd. Zaadbelangen 11, 1957: 184.

Todenbur C. M. Vervoer van slazaadteeltkroppen over grote afstand. Zaadbelangen 11, 1957: 198.

Brons, H. A. Proeven met rozenonderstammen op het I.V.T. De Boomkwekerij 12, 1957 : 170-171.

Huyskes, J. A. Advising and private enterprise. Fatis Review 4, 1957: 105-107.

Kronenberg, H.G. en L. M. Wassenaar. Oranda, een nieuw aardbeiras yoor de teelt onder glas. Groenten en Fruit 13, 1957: 63 .

Nieuwhof, $M$. Praktijkproeven. Groenten en Fruit 13, 1957: 312-313.

Nieuwhof, M. Praktijkproeven met spitskool. Groenten en Fruit 13, 1957: 337-338.

Huyskes, J. A. Witlofkwaliteit en witlofselectie. Zaadbelangen 11, 1957: 352-354.

Huyskes, J. A. Rabarbervirus is goed te bestrijden. Groenten en Fruit 13, 1957: 473.

Gerritsen, C. J. De buitenperzik. Meded. Dir. Tuinb. 20, 1957: 723-730.

Floor, J. De apparatuur voor het stekken onder waterverneveling. Meded. Dir. Tuinb. 20, 1957: 685-689. 
